\title{
The influence of social media service quality on client loyalty in the South African banking industry
}

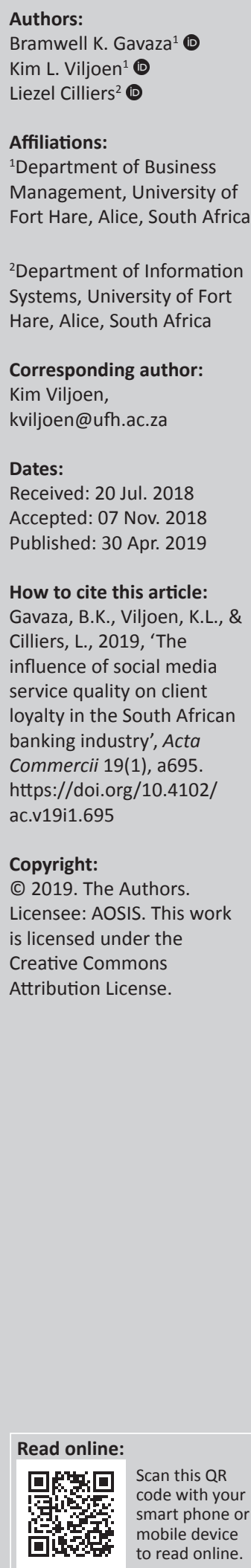

Orientation: The impact and growth rates of Facebook and other forms of social media have made it imperative for all businesses to ensure they have social media strategies in place.

Research purpose: The purpose of this study was to measure the influence of social media service quality on client loyalty in the South African banking industry.

Motivation for the study: There are limited studies conducted in developing countries such as South Africa that focused specifically on the social media service quality and client loyalty in the banking industry.

Research design, approach and method: The study used a quantitative approach and a descriptive research design to test the proposed hypotheses. An online survey on Facebook was used to collect the data from a sample of 377 respondents who had interacted with the five major banks in South Africa on the said platform. A snowball sampling technique was used to identify the appropriate respondents. The data was analysed with Structural Equation Modelling (SEM) to assess the model fit.

Main findings: Findings of the research study proved that the social media system's availability, fulfilment and privacy have a significant influence on the overall service quality of social media, which leads to client loyalty in the South African banking industry.

Practical/managerial implications: The study recommended that managers and marketers should constantly evaluate, monitor and improve the overall service quality of social media offered to their clients, as it leads to a corresponding increase in client loyalty in the South African banking industry.

Contribution/value-add: The study provided empirical evidence, which contributed to the body of business and marketing knowledge in a South African banking context.

Keywords: social media; service quality; client loyalty; banking industry; E-Social ServQual.

\section{Introduction}

Web 2.0 technologies are the phase of Internet development that is characterised by the change from static web pages to user-generated content and, subsequently, the growth of social media (McNutt 2014). The advent of the Internet has revolutionised the way in which businesses have operated during the past two decades. In today's market-driven system, almost all businesses are embracing the economic benefit of digital transformation. The Internet has made it easier for businesses to position and differentiate themselves strategically from competitors, thereby maximising profits. The Internet has made communication with clients simpler, more efficient and, most importantly, it has eliminated geographical barriers between businesses and their clients (Ariff et al. 2012). In this trend, the impact and growth rates of Facebook and other forms of social media have made it imperative for all banks to ensure they have social media strategies in place.

Social media networks, such as Facebook, have become an essential communication tool with which businesses can interact with clients. Facebook currently has almost a billion users worldwide and over 3 million users reside in South Africa (SA) alone (Bevan-Dye \& Akpojivi 2016; Goldstuck 2015). This broad base of Facebook users makes it an ideal social media tool to investigate social networking sites in this study as all the major South African retail banks have included Facebook in their marketing strategy (Moodley \& Govender 2016). Banks are embracing Facebook because they are finding it challenging to compete with traditional methods such as interest rates and product differentiation to attract and maintain clients. 
In today's highly dynamic and competitive environment, retail banks can gain client loyalty through offering superior service quality to ensure maximum client satisfaction (Khan \& Fasih 2014). Therefore, the purpose of this study is to investigate the influence of social media service quality on client loyalty in the South African banking industry context. E-social media service quality through a valid and reliable scale should become an integral part of any bank's effort to improve service quality levels, which are a crucial determinant of client loyalty.

Social media service quality can be used to enhance client loyalty by marketers in the South African banking industry (Potgieter \& Naidoo 2017). There are limited studies that have been conducted on social media service quality and client loyalty in SA (Braendle, Sepasi \& Rahdari 2014; Duffet 2015). This study will contribute towards bridging the existing knowledge gap on the impact of social media on service quality and client loyalty in the South African context. These characteristics will help to improve the e-service quality offered by South African banks to keep pace with global trends and will also provide insight into the South African banking industry's social media client service quality and loyalty intentions.

The article is structured as follows: The next section will provide a discussion on the use of e-social media service quality and client loyalty in the South African banking industry, followed by a discussion on the methodology that was used for data collection, then a presentation of the results. The last section provides the study's findings and conclusion.

\section{Underpinning literature E-SOCIAL-SERVQUAL and client loyalty in the banking industry}

The banking industry embraced the use of social media by developing some alternate delivery channels to attract techsavvy clients, improve client service quality and ensure client loyalty (George \& Kumar 2014). The use of social media in the South African banking industry has gained full acceptance among clients. Even though there are many popular social media platforms among South Africans such as Twitter, LinkedIn and Instagram (Goldstuck 2015), Facebook is leading the trend, having a combined total of 3909792 active users on the five major South African banks' Facebook pages. Thus, there is a need to measure the service quality of the service interactions that are ongoing on banks' Facebook pages.

The use of Facebook has enhanced branding and improved receptiveness to the banking industry (Potgieter \& Naidoo 2017). As clients embrace e-services, banks are increasingly exposed to more significant levels of competition from within the industry, including non-bank financial service businesses. Thus, the intense competition and ever-changing client demands necessitated a specific instrument to measure, evaluate and improve the e-services offered via social media platforms to maintain or gain market share (Petnji-Yaya, Marimon \& Fa 2012). In response to this necessity, an E-SOCIAL-SERVQUAL scale was developed to accommodate the evaluation of the quality of e-services offered via social media sites (Venugopal \& Priya 2015). Although banking transactions are not being conducted on social media platforms, clients are turning to these platforms to engage on a host of issues, such as client inquiries; handling of complaints; advertising of new banking services; and dissemination of banking information (Maphakisa 2014).

The E-SOCIAL-SERVQUAL has similar dimensions to those of E-SERVQUAL, namely system availability, efficiency, fulfilment and privacy. However, E-SOCIAL-SERVQUAL primarily focuses on the services offered on social media (Kim 2015). For this study, the dimensions of E-SERVQUAL have been adapted to incorporate a different context that is evaluating the service offered in the South African banking industry via social media.

Social media sites facilitate efficient and effective bank-client service interaction (Amin 2016). This interaction has directed many banks in SA to offer social media services and continuously strive to improve their service quality by providing superior levels of this to clients (Salehnia et al. 2014). The success of e-banking does not depend on the presence of an attractive Facebook page and low banking rates but rather on superior e-service quality (George \& Kumar 2014). However, it has become increasingly difficult for banks to compete making use of e-services to attract and retain clients (Redda 2015). Thus, client loyalty has been an important goal for banks (Salehnia et al. 2014), and in this study client loyalty intention was added to the E-SOCIALSERVQUAL model to evaluate service quality and its impact on the South African banking industry.

South African banks need to know the social media service quality dimensions that have higher levels of client expectations so that they can create a more conducive e-service environment and deliver experiences that exceed clients' expectations. The five dimensions of the E-SOCIALSERVQUAL measurement scale concerning the social media context (mainly Facebook) of this study are discussed below.

\section{Social media system availability}

System availability is regarded as the correct technical functioning of the retail bank's Facebook page (Kim 2015). Clients expect Facebook brand pages to be available always, client friendly (intuitive) and fast when downloading useful and relevant content (Durkin, McGowan \& Murray 2014). Through system availability, there has been an increase in the accessibility of the banks' Facebook pages through the feature of client self-service (Okeke, Ezeh \& Ugochuckwu 2015). This accessibility aids in reducing the bank's operational costs and, from the client's perspective, saves time and is costeffective (reduction) because clients can access the bank information anytime and from any place. 
Facebook page design is a determinant of client loyalty in e-services in SA and Australia (Quach, Thaichon \& Jebarajakirthy 2016). Social media site characteristics, such as ease of use and relevant information, are significant influencers of client loyalty in e-service-based businesses. Even though system availability influences client loyalty towards a bank, it should be noted that retail banks rely on the technology provided by the social media companies, and this is beyond banks' control. The following hypothesis was thus formulated:

$\mathbf{H}_{1}$ : Social media system availability significantly influences overall social media quality in the South African banking industry.

\section{Social media efficiency}

The efficiency dimension of E-SOCIAL-SERVQUAL focuses on two separate elements, namely, the Facebook page and the bank service on the Facebook page. 'Efficiency' refers to the ease, speed and convenience with which clients can access a retail bank's Facebook page (Petnji-Yaya et al. 2012). Efficiency evaluates the speed of accessing and using the bank's Facebook site to facilitate completion of all required interaction in a convenient way (Ariff et al. 2012). Social media can enhance the traditional personnel-client relationship with an effective technological knowledge-based relationship (Venugopal \& Priya 2015).

There is a need for retail banks to respond efficiently to clients' requests on Facebook and to provide them with the relevant information required. Quick responses to clients' needs and queries are imperative for the improvement of service value when e-banking services are offered (Okeke et al. 2015). Bank clients are likely to be satisfied with a bank's Facebook site when it matches or exceeds the abilities of an experienced member of the bank's personnel (George \& Kumar 2014). This client satisfaction can only be met if bank personnel combine client service with technology (Kalia 2017). Client service combined with technology provides a unique banking experience offered to the client. Thus, it is necessary to research and assess how well bank personnel respond to queries on Facebook pages. Against this background, the following hypothesis was formulated:

$\mathbf{H}_{2}$ : Social media efficiency significantly influences overall social media quality in the South African banking industry.

\section{Social media fulfilment}

Fulfilment focuses on the service accuracy and availability of relevant information provided on a bank's Facebook site (Yarimoglu 2015). The fulfilment dimension consists of measures about the requirements of clients regarding the promptness of a bank's Facebook page and the confirmation of the selected service (George \& Kumar 2014). Through the fulfilment dimension, retail banks create user-generated content, which is the most significant predictor of client loyalty intention in the banking industry (Einasto 2014).
Fulfilment is akin to the refined assurance measurement of SERVQUAL and focuses on the client's confidence when using the bank's Facebook site and the extent to which client requirements are fulfilled in the social media interaction (Ariff et al. 2012). Based on this discussion, the following relationship was hypothesised:

$\mathbf{H}_{3}$ : Social media fulfilment significantly influences overall social media quality in the South African banking industry.

\section{Social media privacy}

Privacy deals with the degree to which a bank's social media platform is safe and how it protects client details (Kim 2015). There is a need to exude confidence among bank clients so that they perceive their personal information to be secure and protected on the bank's Facebook page and that the bank will not misuse their personal information (Darmayanti \& Cahyono 2014). As a result of positively perceived social media privacy, retail banks can build new relationships with clients based on mutual trust (Mushwana \& Bezuidenhout 2014). The ease with which information may be disclosed and shared on Facebook has raised serious privacy concerns among scholars and social critics (Bevan-Dye \& Akpojivi 2016).

Maintaining the privacy of a bank's Facebook page remains a real challenge for the banking industry. The primary challenge is the fact that it is difficult to manage and control uploads on the Facebook site (Mushwana \& Bezuidenhout 2014). Indeed, low privacy settings of Facebook sites may expose clients to privacy invasion and even make them vulnerable to criminal activities such as identity theft. There have been several cases of cloned social media profiles: for example, in SA in May 2013, Facebook accounts were cloned by criminals who targeted the friends of the owners of the cloned accounts and solicited money from them (Bevan-Dye \& Akpojivi 2016). The banking business involves risks, and with the integration of Facebook into banking service channels, the degree of danger increases. Based on the discussion above, the following relationship was hypothesised:

$\mathbf{H}_{4}$ : Social media privacy significantly influences overall social media quality in the South African banking industry.

\section{Social media overall service quality}

The measurement of social media quality in the South African banking context has received little attention (Redda 2015). There is a general agreement among scholars that banks must consider the overall social media service quality dimension to satisfy clients and enhance their performance profitability (Khan \& Fasih 2014). When clients are satisfied with the overall social media service quality attributes, the service experienced by a client is satisfactory and will contribute to the intention of the client to commit to a consistent relationship with the bank. The improvements in social media quality in the banking industry lead to a corresponding increase in overall client satisfaction, which in turn leads to 
client loyalty (Martin 2016). The following hypothesis was subjected to testing in this study:

$\mathbf{H}_{5}$ : Social media's overall service quality significantly influences clients' loyalty intention in the South African banking industry.

\section{Client loyalty intention}

Many service businesses have developed client loyalty programmes as part of relation-development activities. The challenging business environment has led banks to be innovative and use other alternative services to attract more clients and instil client loyalty (Redda 2015). The banks rely on service quality that leads to client satisfaction, which is an indicator of client loyalty intention.

Clients extend robust loyalty to banks when they believe the bank prioritises their interests (Khan \& Fasih 2014). When all the E-SOCIAL-SERVQUAL dimensions are satisfactory, clients can perceive superior overall service quality, which leads to the client's loyalty intention. Client loyalty consists of two dimensions, namely behavioural loyalty and attitudinal loyalty. The behavioural aspect of loyalty focuses on a measure of the proportion of purchase of a specific brand, while attitudinal loyalty is measured by a psychological commitment to a bank (Darmayanti \& Cahyono 2014). Banking service quality influences both attitudinal and behavioural loyalty (Quach et al. 2016); hence this study focused on both attitudinal and behavioural loyalty.

There are several benefits that are associated with clients' loyalty intentions in the banking industry, for example, decreasing clients' price sensitivity, banks' survival and sustainability, positive word of mouth (WOM), reduced costs and protection against competition (Redda 2015). Therefore, in this study, client loyalty becomes an important aspect for South African banks to consider when aiming to yield optimal economic benefit. Thus, periodic measurement of the levels of e-social service quality, through valid and reliable scales, should become an integral part of any bank's effort to improve service quality levels, which are a key determinant of client loyalty (Martin 2016). Given the discussion from the preceding sections, it is necessary for the present study to test all five dimensions of E-SOCIALSERVQUAL and their resultant impact on client loyalty as illustrated in Figure 1.

\section{Research method and design}

A positivistic paradigm was adopted because of its compatibility with the set objectives regarding social media service quality. A deductive approach was used to present the nature of the relationship between social media service quality and client loyalty in the South African baking industry context. Quantitative data was collected, and accordingly a descriptive research design was deemed most suitable for this study (Wiid \& Diggines 2015). A quantitative research approach was used to collect primary data, making

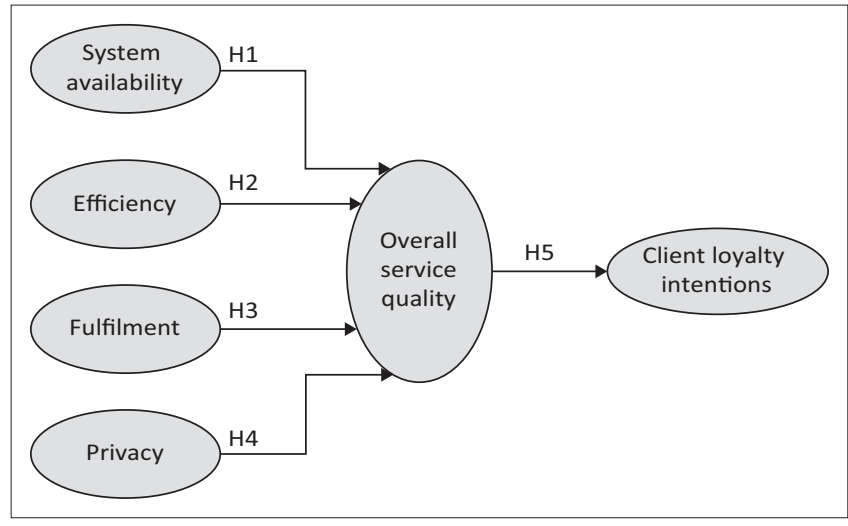

Source: Gavaza, B.K., 2017, 'The influence of social media service quality on client loyalty in the South African banking industry', Masters dissertation, East London, University of Fort Hare, Eastern Cape

FIGURE 1: The conceptual model.

use of an online questionnaire. Quantitative research methods aided in the generalisation of the study outcomes (Bryman \& Bell 2015).

The study focused on the five major retail banks in SA. The population of this study was drawn from Facebook users who use their accounts to interact with retail banks in SA. There is a combined total (population) of 3909782 users on these five major banks' Facebook pages. The sample size consisted of 377 respondents, and they were selected using a non-probability snowball sampling approach. The researcher contacted friends and colleagues who were using Facebook banking information and encouraged them to invite other Facebook users to the Facebook page where the link to the online questionnaire was available. An online survey was conducted; the questionnaire used contained scales that were a derivation of the E-SERVQUAL measurement instrument. The E-SERVQUAL research tool is a valid and reliable instrument that was tested in various studies across different service industry settings (Parasuraam, Zeithaml \& Malhotra 2005). The derivation of the E-SERVQUAL instrument took the form of the E-SOCIAL-SERVQUAL measurement scale, which was used for the purposes of this study. This instrument had previously been adapted for a social media service setting (Kim 2015). The questionnaire was administered online through a Facebook page titled 'Social Media Service Quality in the South African Banking Industry'. A link with a set of questions was posted on the page and bank clients used the link to access the questionnaire. Respondents were directed to the study's Facebook page through public posts on banking-related Facebook pages, which was designed to request participation.

The data were analysed through the use of the Statistical Package for the Social Sciences (SPSS) (Version 24) and the structural equation modelling (SEM) program Lisrel (Version 9). The SPSS was used for the descriptive statistics, reliability and validity testing of the constructs while SEM was used to assess the conceptual model. Confirmatory factor analysis was used to compute the structural and measurement models. 
Various fit indices such as $t$-values, $p$-values and path coefficients were used to assess the model fit. The value of $t$-test statistics generated should exceed the critical value of 1.96 for the null hypothesis to be rejected, and $p$-values were considered significant at $<0.05$, that is, at a $95 \%$ confidence interval (Hair et al. 2014). The path coefficients with values less than 0.10 were considered to have a weak effect; values close to 0.30 indicated a moderate effect; and values greater than 0.50 were considered to have a strong effect (Suhr 2006).

\section{Ethical consideration}

An ethical clearance certificate (reference number: VIL131SGAV0) to conduct the study was obtained from the University of Fort Hare Research Ethics Committee.

\section{Results}

\section{Biographical profile of applicants}

There was a fair representation of both genders in the study, although males were slightly more represented than their female counterparts: out of 377 respondents, $45.6 \%$ were female, and $53.3 \%$ were male. The sample size consisted of respondents who ranged from age 18 years and older. The age group between 25 and 34 years constituted $46.2 \%$ of the total respondents. Most of the respondents (49.9\%) had been using Facebook for more than 6 years. A total of $34.7 \%$ respondents had been using Facebook for a period of between 3 and 5 years, while $14.9 \%$ had been making use of Facebook for less than 2 years.

The respondents indicated that they were familiar with Facebook in general and how helpful it was for various purposes. This study found that $48.5 \%$ of the respondents used Facebook to search for banking information on a daily basis. Results indicated that $15.4 \%$ of respondents made use of Facebook for banking information on a weekly basis, $12.5 \%$ did so on a monthly basis and $22.8 \%$ used it only occasionally. There was a fair representation of banks, with Capitec Bank and Standard Bank having the largest number of participants, with each contributing $23.3 \%$ of the total sample size. ABSA, or Amalgamated Banks of South Africa, clients constituted $18.8 \%$ of respondents, while First National Bank (FNB) and Nedbank clients constituted 18.0\% and $16.2 \%$, respectively. The respondents were drawn from all nine provinces of SA, with most of the respondents residing in the Eastern Cape Province, which comprised $38.7 \%$ of the survey participants.

\section{Results of the reliability and validity analysis}

Factor loadings and Cronbach alpha coefficients were the criteria used to determine the validity and reliability of the constructs, respectively. Table 1 provides a combined summary of validity and reliability analysis.

All constructs proved to be unidimensional, with relatively high factor loading ranges recorded. The Cronbach's alpha coefficient was used to assess if the measure of the scale was
TABLE 1: Reliability and validity summary.

\begin{tabular}{lccc}
\hline $\begin{array}{l}\text { Construct and/or } \\
\text { variables }\end{array}$ & Number of items & Factor loading range & Cronbach's alpha \\
\hline $\begin{array}{l}\text { Social media system } \\
\text { availability }\end{array}$ & 4 & $0.750-0.849$ & 0.814 \\
Social media efficiency & 7 & $0.539-0.746$ & 0.824 \\
Social media fulfilment & 4 & $0.693-0.815$ & 0.746 \\
Social media privacy & 3 & $0.777-0.818$ & 0.727 \\
$\begin{array}{l}\text { Social media overall } \\
\text { service quality }\end{array}$ & 4 & $0.710-0.821$ & 0.777 \\
Client loyalty intention & 5 & $0.700-0.801$ & 0.771 \\
\hline
\end{tabular}

reliable and a Cronbach's alpha coefficient of more than 0.7 was considered significant for this study (Pallant 2016). All of the constructs of the E-SOCIAL-SERVQUAL model as well as the dependent variable scale used for this study computed a good degree of reliability and satisfactory evidence of construct validity.

\section{Goodness of fit indices for measurement and structural model}

The overall fit for both the measurement and structural models measured showed a $p$-value of 0.000 , which indicates statistical significance. Concerning the measurement model, the Root Mean Square Error of Approximation (RMSEA) figure score of 0.045 reported is below the maximum required RMSEA of 0.5 (Wuensch 2013), which suggests a close fit between the data and the model. The comparative fit index (CFI) reported a value of 0.981, which is above the recommended value of 0.9 . Thus, there was a perfect fit between the data and the model. The study findings reported a normed fit index (NFI) value of 0.958 and a non-normed fit index (NNFI) value of 0.978 . These indices are close to 1 . Thus, they are a good fit for the data and model. All other fit indices had values between the required range of 0 and 1 . The indices above stipulate that the measurement model was valid; hence next phase to be assessed was the structural model.

Concerning the fit of the structural model, a RMSEA value of 0.048 reported for this study is statistically significant regarding its structural fit as it is below the maximum allowed RMSEA of 0.05 . The NFI and NNFI reported 0.955 and 0.976 , respectively, which is strong evidence of good fits for a structural model. The other reported statistics also proved to be a good fit for the structural model and were recorded as follows: parsimony normed fit index 0.847; CFI 0.979; incremental fit index 0.979 and relative fit index 0.950 . These statistics were close to 1 , which indicates a good fit for the structural model. Therefore, it can be concluded that the model is significant and regarded as a perfect fit. Figure 2 provides the structural model for this study.

\section{Estimation}

The maximum likelihood estimation method was employed to estimate the path coefficients of the structural model. These path coefficients explained the correlation strength between variables. The variables' correlation strength was analysed using a beta matrix as depicted in Table 2 . The path 




Note: Chi-square $=527.58, d f=255, p$-value $=0.00000$, RMSEA $=0.045$.

RMSEA, root mean square error of approximation.

FIGURE 2: Structural model.

TABLE 2: Relationships between E-SOCIAL-SERVQUAL variables and client loyalty intentions.

\begin{tabular}{|c|c|c|c|c|}
\hline Alternate hypotheses & Path coefficient & $t$ & $p$ & Reject hypotheses \\
\hline $\begin{array}{l}\mathrm{H}_{1} \text { : Social media system availability significantly influences overall social media quality in the } \\
\text { South African banking industry. }\end{array}$ & 0.19 & 1.990 & 0.0475 & No \\
\hline $\begin{array}{l}\mathrm{H}_{2} \text { : Social media efficiency significantly influences overall social media quality in the South } \\
\text { African banking industry. }\end{array}$ & 0.05 & 0.290 & 0.7720 & Yes \\
\hline $\begin{array}{l}\mathrm{H}_{3} \text { : Social media fulfilment significantly influences overall social media quality in the South } \\
\text { African banking industry. }\end{array}$ & 0.36 & 2.751 & 0.0063 & No \\
\hline $\begin{array}{l}\mathrm{H}_{4} \text { : Social media privacy significantly influences overall social media quality in the South } \\
\text { African banking industry. }\end{array}$ & 0.41 & 4.126 & 0.0001 & No \\
\hline $\begin{array}{l}\mathrm{H}_{5} \text { : Social media's overall service quality significantly influences clients' loyalty intention in the } \\
\text { South African banking industry. }\end{array}$ & 0.94 & 7.944 & 0.0001 & No \\
\hline
\end{tabular}

parameters through estimation analysed the findings of the data collected and determined that three variables (privacy, fulfilment and system availability) were strongly correlated to social media overall service quality. However, it also determined that social media efficiency has a weak influence on social media overall service quality in the South African banking industry. $T$-values and path coefficient values depicted the degree of association between social media service quality and client loyalty intention in the South African banking industry as shown in Table 2.

The social media privacy dimension reported the highest path coefficients value of 0.41 , which indicates a stronger influence on social media overall service quality as compared to other independent variables. The social media fulfilment dimension recorded a path coefficient value of 0.36 , placing the variable as the second highest regarding strength of influence on social media overall service quality in the South African banking industry.

Social media system availability reported a path coefficient value of 0.19 , which positioned it as the third highest independent variable regarding its strength to influence social media overall service quality in the South African banking industry. The social media efficiency dimension recorded a weaker path coefficient value of 0.05 , which shows it as 
having the least influence on social media overall service quality in the South African banking industry.

Three of the independent variables (privacy, fulfilment and system availability) had a significant effect on social media overall service quality in the South African banking industry, while efficiency did not have a significant effect. The social media overall service quality variable reported a high path coefficient score of 0.94 , which is close to 1 . The closer the path coefficient value is to 1 , the stronger the effect of variables. Therefore, social media overall service quality has a strong influence on client loyalty intention in the South African banking industry. The path coefficients and $t$-values from the gamma matrix were employed to test and analyse the significance of the hypotheses for this study. The $t$-values were converted into $p$-values which were then used to statistically test the hypotheses, as illustrated in Table 2.

\section{Assessment of hypotheses}

E-SOCIAL-SERVQUAL was the independent variable used, while client loyalty intention was the dependent variable. A path coefficient range between -1 and +1 , with a $p$-value of 0.05 , was deemed a significant path coefficient score and accepted in this study.

\section{Discussion}

The discussion is provided in respect to each study variable, starting with the discussion on social media efficiency.

\section{Social media efficiency}

There is a significant relationship between social media efficiency and overall service quality in the South African banking industry. However, social media efficiency has the lowest path coefficient score of 0.05 in comparison to other E-SOCIAL-SERVQUAL variables, which showed a weaker correlation. Social media efficiency's inconsequential influence on overall service quality in the South African banking industry is as a result of client perception that there is nothing much being done by banks regarding improving efficiency on their social media platforms. Because banking transactions cannot take place on Facebook, this conclusion is one that is conceivable. This conclusion possibly explains why these findings within the context of the banking industry contradict the findings of other studies that confirmed a positive relationship between social media efficiency and overall service quality in other industries (Kim 2015; Venugopal \& Priya 2015). Even though social media efficiency has the lowest path coefficient score in the South African banking industry, clients still expect to use a simple, speedy and conveniently accessible bank Facebook page.

\section{Social media system availability}

Social media system availability significantly influences overall service quality in the South African banking industry. This finding validates studies conducted by Kim (2015),
Persad and Padayachee (2015) and Quach et al. (2016), who revealed similar findings. Therefore, the study concludes that a bank's Facebook page availability plays a significant role in shaping social media sites. However, the path coefficient of 0.19 indicated that social media system availability was the second weakest dimension regarding its influence on overall service quality. This might be as a result of clients having felt that even though they need the bank social media platforms to always be available, banks cannot control the technical aspects of these sites. The total control of these social media websites rest with the mother company of these social media platforms, such as Facebook.

\section{Social media fulfilment}

Social media fulfilment significantly influences overall service quality in the South African banking industry. The findings of a positive relationship are also supported in the literature section (George \& Kumar 2014; Kim 2015; Yarimoglu 2015). Marketers should, therefore, emphasise social media fulfilment because it has the second-strongest influence (path coefficient score of 0.36) on overall service quality in the South African banking industry. Clients expect retail banks to fulfil their promises regardless of circumstances or platforms used. Clients utilise the social media fulfilment component to measure the bank's reliability. That is, if they can count on the bank information supplied or trust the bank's service or product offerings conveyed via social media, then they feel fulfilled. Thus, social media fulfilment's high influence on overall service quality in the South African banking industry shows the degree to which clients expect accurate and reliable information to be delivered via social media.

\section{Social media privacy}

Social media privacy significantly influences overall service quality in the South African banking industry. The study findings revealed that clients highly value the social media privacy dimension in the South African banking industry. This confirmed research studies that were conducted in other countries such as in Britain by Datta (2010) and Amin (2016), which ranked the privacy of banks' social media sites as the most important attribute of social media service quality. Social media privacy had the strongest influence (path coefficient score of 0.41 ) on overall service quality. This is as a result of the increase in cybercrimes. Therefore, clients consider privacy as their priority for practising safe banking. The degree of privacy on social media reduces clients' vulnerability; thus its (privacy) provision is associated with satisfactory overall service quality.

\section{Overall service quality of social media and client loyalty conclusions}

The empirical findings revealed that the overall service quality of social media significantly influences client loyalty intention in the South African banking industry. This study finding corresponds with those of other studies 
(Kalia 2017; Martin 2016; Potgieter \& Naidoo 2017; Quach et al. 2016), as discussed in the literature section. South African clients active on social media carefully evaluate social media service quality when considering the level of loyalty they assign to their respective banks. For banks to enjoy the benefits of client loyalty in the South African banking industry, they should be concerned about all the social media service quality underpinnings and dedicate themselves to ensuring satisfactory overall service quality.

The strong influence of the overall social media service quality observed (path coefficient score of 0.94 ) on client loyalty in the South African banking industry is as a result of clients' desire to obtain satisfactory banking services experiences in a social media context. The social media overall service quality is an umbrella to all service quality variables. Therefore, clients prefer a bank that offers them an experience that comprises all their service needs.

\section{Managerial implications and recommendations}

This study contributed to the theoretical and empirical body of knowledge in the fields of Business Management, Marketing Management and the banking industry. It bridged the existing knowledge gap in the current literature with specific reference to the impact of social media on service quality and client loyalty in the South African banking industry context. The study provided new knowledge regarding the influence and contribution of E-SOCIALSERVQUAL variables on overall social media service quality in the South African banking industry. This could aid managers in better understanding the specific social media service quality dimensions on which to focus when addressing client loyalty intentions in the South African banking industry. The study findings indicated the best demographic category (market niche) for marketers to target when conveying banking information on social media platforms in South Africa. This market niche consisted of the majority age group of 25-34 years, which was highly responsive to this study.

In terms of efficiency it is recommended that a bank have more bank personnel working on social media accounts to ensure that clients are responded to within a short space of time. Furthermore, South African banks should ensure that all queries on their social media platform are followed up timeously to check if they were resolved. South African banks should also strive to improve social media efficiency and instil its importance in client perception so that they can be loyal to the bank. Regarding system availability, it is recommended that banks constantly upgrade their systems, networks, servers and storage capacity system to support the growing demand for e-social media services. South African banks should use different network providers, so that if one provider's network is down, they can switch to a different one. Moreover, there should be bank personnel available or on standby at all times to make these network adjustments. In addition, South African banks should put more emphasis on the correct technical functioning of their Facebook page. This will help them to have a highly responsive Facebook site that can react professionally to client requirements and complaints.

For the fulfilment variable, it is recommended that the information on banks' Facebook pages always match their products or services, because clients anticipate experiencing the service quality or seeing the exact products as they appear on social media platforms, to fulfil their expectations. Furthermore, South African banks should continuously train their employees so that they can deliver the service or product offering satisfactorily, as advertised on social media platforms. This will enhance overall service quality, which in turn leads to client loyalty. South African banking industry managers and marketers should also ensure those client requirements are fulfilled within the promised time frame, as this will help to build and strengthen the bank-client relationship.

At the privacy level, it is suggested that the South African banks constantly educate clients on social media banking rules. For instance, clients should never give banking details on public platforms as this makes them vulnerable to criminal activities. Banks must take complaints of a serious or invasive nature offline, that is, the bank should contact the client directly when there is a problem with his or her account. This will reduce the risk of privacy invasion and enhance the service quality offered to the client, who in turn will lean towards greater client loyalty. In addition, South African banks should have expert personnel who constantly research cybercrime trends to protect clients from potential frauds and scams. These experts should be visible on bank social media platforms to mitigate risk and educate clients about privacy.

With respect to social media overall service quality and client loyalty, it is recommended that South African banks have personnel who are determined to build a social media culture including creating social media as a vital component for the marketing of banks. Furthermore, proper and continuous staff training in the South African banking industry should be conducted to achieve and maintain the high level of competency and service reliability in the fast-changing technological landscape, in particular with relation to social media trends. Banks should have different personnel who deal with specific e-social media service dimensions to enhance specialisation, which will result in a higher level of service quality on social media sites and will, in turn, lead to client loyalty.

In addition, South African banks should hire social media research personnel who will focus on analysing client interactions on social media and create compatible services or product offerings that suit clients' lifestyles. This can help the banks to understand new needs regarding products and services because the social media sites present novel interactional platforms. Banks should also present the banking information in an easy and educational way under the bank's brand name. This will satisfy most of the clients who do not have much time to spend searching 
banking-related information, and these clients are likely to be loyal to the platform that they find the easiest and most informative to them.

The study only focused on the top five banks, ABSA, FNB, Standard Bank, Nedbank and Capitec, in South Africa. Future research might attempt to conduct a survey on other South African banks or instead survey more than these five banks, as this would develop a theoretical rationale to better understand social media service quality and client loyalty intent in the South African banking industry. The present research study only focused on the Facebook pages of these banks, whereas future studies could examine other widely used social media platforms. The present study was conducted in SA. Therefore, further research studies should not be limited to South African banks only but extend to other developing countries within the African region.

\section{Conclusion}

The South African banking industry has traditionally been a high contact service offering. The lack of direct human interaction in e-service settings accentuates the need to examine service quality offered and how clients perceive it, utilising the E-SOCIAL-SERVQUAL instrument. Even though clients are satisfied with traditional banking, their expectations are continuously growing because of enhanced technology including social media tools. This study concluded that social media system availability, fulfilment and privacy have a significant influence on the overall service quality of social media in the South African banking industry. Thus, it is recommended that South African banks prioritise social media service quality attributes in their marketing mixes because clients mainly consider these aspects of the social media service offered to them, before considering being loyal to banks.

\section{Acknowledgements Competing interests}

The authors declare that they have no financial or personal relationships that may have inappropriately influenced them in writing this article.

\section{Authors' contributions}

B.K.G. collected data and wrote the initial draft of the article, K.L.V. supervised and refined the final draft of the article and L.C. co-supervised and refined the second draft of the article.

\section{Funding}

The research study was partly funded by Dr K.L. Viljoen's Seed Grant Account (C135) from University of Fort Hare and partly Thuthuka Grant National Research Fund (used to pay statistician and language editor), with grant number TTK150713125504. In addition, supervisor-linked bursaries from both Dr K.L. Viljoen and Dr L. Cilliers also funded the study.

\section{References}

Amin, M., 2016, 'Internet banking service quality and its implication on e-customer satisfaction and e-customer loyalty', International Journal of Bank Marketing 34(3), 280-306. https://doi.org/10.1108/IJBM-10-2014-0139

Ariff, M.S., Yun, L.O., Zakuan, N. \& Jusoh, A., 2012, 'Examining dimensions of electronic service quality for Internet banking services', Procedia-Social and Behavioural Sciences 65, 854-859. https://doi.org/10.1016/j.sbspro.2012.11.210

Bevan-Dye, A.L. \& Akpojivi, U., 2016, 'South African generation Y students' selfdisclosure on Facebook', South African Journal of Psychology 46(1), 114-129. https://doi.org/10.1177/0081246315602645

Braendle, U., Sepasi, S. \& Rahdari, A.H., 2014, 'Fuzzy evaluation of service quality in the banking sector: A decision support system', Fuzzy Economic Review 19(2), 47-79. https://doi.org/10.25102/fer.2014.02.04

Bryman, A. \& Bell, E., 2015, Business research methods, 5th edn., Oxford Press, Oxford

Darmayanti, D. \& Cahyono, H., 2014, 'The influence of perceived service quality, attitudinal loyalty and corporate social responsibility on repeat patronage intention in retail banking in Indonesia', Journal of Business and Retail Management Research 8(2), 16-21.

Datta, S.K., 2010, 'Acceptance of e-banking among adult customers: An empirical investigation in India', Journal of Internet Banking and Commerce 15(2), 1-17.

Duffet, R., 2015, 'Facebook advertising's influence on intention-to-purchase and purchase amongst millennials', Internet Research 25(4), 498-526. https://doi. org/10.1108/IntR-01-2014-0020

Durkin, M., McGowan, P. \& Murray, L., 2014, 'Perspectives on the potential for social media to improve communication in small business-bank relationships', The International Journal of Entrepreneurship and Innovation 15(4), 251-264. https:// doi.org/10.5367/ijei.2014.0163

Einasto, O., 2014, 'Investigating e-service quality criteria for university library: A focus group study', New Library World (115)(1/2), 4-14.

Gavaza, B.K., 2017, 'The influence of social media service quality on client loyalty in the South African banking industry', Masters dissertation, East London, University of Fort Hare, Eastern Cape.

George, A. \& Kumar, G.G., 2014, 'Impact of service quality dimensions in internet banking on customer satisfaction', $A$ decision 41(1), 73-85. https://doi. org/10.1007/s40622-014-0028-2

Goldstuck, A., 2015, Social media usage by SA brands, South African Social Media Landscape 2015, viewed 15 January 2017, from http://www.worldwideworx. com/wp-content/uploads/2014/11/Exec-Summary-Social-Media-2015.pdf

Hair, J.F., Black, W.C., Babin, B.J. \& Anderson, R.E., 2014, Multivariate data analysis, 7 th edn., Pearson, Pearson Harlow, Essex.

Kalia, P., 2017, 'Service quality scales in online retail: Methodological issues', International Journal of Operations \& Production Management 37(5), 630-663. https://doi.org/10.1108/IJOPM-03-2015-0133

Khan, M.M. \& Fasih, M., 2014, 'Impact of service quality on customer satisfaction and customer loyalty: Evidence from the banking sector', Pakistan Journal of Commerce and Social Sciences 8(2), 331-354.

Kim, H.M., 2015, 'The applicability of ES-QUAL for assessing the service quality of social media services in academic libraries', Doctoral dissertation, Drexel University.

Maphakisa, M.D., 2014, 'Effectiveness of ABSA business bank's customer relationship management practices in maintaining loyalty among customers in the Eastern Cape Province', Doctoral dissertation, Central University of Technology, Free State, Bloemfontein.

Martin, M.J., 2016, 'Clients' determination of service quality and satisfaction in a return/repair process. A quantitative study', Academy of Marketing Studies Journal 20(1), 36-52.

McNutt, K., 2014, 'Public engagement in the Web 2.0 era: Social collaborative technologies in a public sector context', Canadian Public Administration 57(1), 49-70. https://doi.org/10.1111/capa.12058

Moodley, T. \& Govender, I., 2016, 'Factors influencing the academic use of internet banking services: An empirical study', African Journal of Science, Technology, Innovation and Development 8(1), 43-51.

Mushwana, G. \& Bezuidenhout, H., 2014, 'Social media policy in South Africa', Southern African Journal of Accountability and Auditing Research 16, 63-74.

Okeke, T.C., Ezeh, G.A. \& Ugochuckwu, N.O., 2015, 'Service quality dimension and customer satisfaction with online services of Nigerian banks', The Journal of Internet Banking and Commerce 20(3), 2-9.

Pallant, J., 2016, SPSS survival manual: A step by step guide to data analysis using IBM SPSS, 6th edn., McGraw-Hill, New York.

Parasuraam, A., Zeithaml, V.A. \& Malhotra, A., 2005, 'ES-QUAL a multiple-item scale for assessing electronic service quality', Journal of Service Research 7(3), 213-233. https://doi.org/10.1177/1094670504271156

Persad, K. \& Padayachee, K., 2015, 'The factors that influence customer e-services adoption', South African Computer Journal 56(1), 80-106. https://doi. org/10.18489/sacj.v56i1.209

Petnji-Yaya, L.H., Marimon, F. \& Fa, M.C., 2012, 'Assessing e-service quality: The current state of ES-QUAL', Total Quality Management \& Business Excellence 23(11-12), 1363-1378. https://doi.org/10.1080/14783363.2012.728850

Potgieter, L.M. \& Naidoo, R., 2017, ‘Factors explaining user loyalty in a social mediabased brand community', South African Journal of Information Management 19(1), 1-9. https://doi.org/10.4102/sajim.v19i1.744 
Quach, T.N., Thaichon, P. \& Jebarajakirthy, C., 2016, 'Internet service providers' service quality and its effect on customer loyalty of different usage patterns', Journal of Retailing and Consumer Services 29(2016), 104-113. https://doi.org/10.1016/j. jretconser.2015.11.012

Redda, E.H., 2015, 'Electronic banking services in South Africa: Service quality scale development and validation', Doctoral dissertation, North-West University.

Salehnia, M., Saki, M., Eshaghi, A. \& Salehnia, N., 2014, 'A model of e-loyalty and word-of-mouth based on e-trust in E-banking services (Case Study: Mellat Bank)' New Marketing Research Journal 4101-4114.
Suhr, D., 2006, The basics of structural equation modelling, SAS User Group of the Western Region of the United States (WUSS), Irvine, CA.

Venugopal, P. \& Priya, A., 2015, 'The impact of customer service on customer relationship management', Global Management Review 10(1), 139-152.

Wiid, J. \& Diggines, C., 2015, Marketing research, 3rd edn., Juta, Cape Town.

Wuensch, K., 2013, An introduction to structural equation modelling (SEM), viewed 03 November 2016, from http://core.ecu.edu//ssyc/wuenschk/statslessons

Yarimoglu, E.K., 2015, 'A review of service and e-service quality measurements: Previous literature and extension', Journal of Economic and Social Studies 5(1), 169-191. 